\title{
Morphogenic change in the cervix of the ewe after prolonged exposure to oestradiol-17ß
}

\author{
N. R. Adams \\ CSIRO Division of Animal Production, P.O., Wembley, Western Australia 6014, Australia
}

\begin{abstract}
Summary. This study examined the effects of prolonged exposure to oestradiol-17 $\beta$ on the morphology of the cervix of the ewe. Merino ewe lambs were implanted subcutaneously with 3 Silastic capsules which released a total of approximately $300 \mu \mathrm{g}$ oestradiol-17 $\beta$ per day. After exposure for 200 days the uterus was more markedly bicornuate, and the cervix was broader and softer, than in controls. The cervical folds were shorter and contained many stromal cells. The amount of lamina propria under the folds was increased and altered so that it contained tubular glands and more stromal cells. The endocervix thus came to resemble endometrium. This appearance developed within 80 days of exposure, and remained for at least 170 days after implant removal. In a second experiment, mature multiparous Merino ewes were ovariectomized and implanted with 1, 2 or 4 similar oestradiol capsules for 140 days. Similar features developed in these ewes, and the degree of change was almost as great with 1 implant as with 4.

Changes of a similar nature can be produced in other species by oestrogen given during organogenesis but not during adult life. The changes indicate that the ewe has an ability to display a degree of morphogenic response to oestradiol during adult life.
\end{abstract}

\section{Introduction}

The cervix of the ewe is a hard collagenous tubular structure with simple longitudinal folds (Raynaud, 1973; Heydon \& Adams, 1979). However, if ewes are exposed to oestrogenic clover pasture for more than 1 year, the structure of the cervix changes so that it looks more like uterus (Adams, 1976). The folds become very much reduced, and the lamina propria becomes more cellular. Coiled, tubular glands appear, and histochemically these stain similarly to uterine glands (Heydon \& Adams, 1977). The surface epithelium changes from stratified squamous epithelium caudally and mucus cells cranially to more uniform columnar non-mucus cells similar to uterine epithelium (Lightfoot \& Adams, 1979). In fact, the only way this tissue can be differentiated from uterus is by the more irregular lumen and by the remnants of fibrous tissue in the surrounding muscle layers. These changes resulting from prolonged exposure to oestrogenic clover are permanent and are associated with a loss of the ability of the cervix to function efficiently as a reservoir for spermatozoa (Lightfoot, Croker \& Neil, 1967). This permanent infertility called clover disease is widespread, although not very severe, in Western Australia (Lightfoot, 1974).

It is most unusual for an organ to be supplanted by an adjacent organ during adult life. This type of change in cellular composition has not been recorded in the cervix of animals of other species, or in ewes that have not been exposed to oestrogenic pasture. In the present study ewes 
were exposed to oestradiol-17 $\beta$ to determine whether the change is simply a response to phytooestrogens, or part of a more generalized response of the ewe to prolonged exposure to steroidal oestrogens. Some of the conditions under which the change may occur were also defined.

Some of these data have been presented previously as abstracts (Adams 1981a, 1983).

\section{Materials and Methods}

Intact prepubertal Merino ewe lambs were implanted in spring (November) at 90 days of age with 3 Silastic tubing implants, which were empty or filled with crystalline oestradiol-17 $\beta$. These animals normally reach puberty at about 260 days old. The implants were made from Silastic tubing (Dow Corning Corp., Midland, MI, U.S.A.; i.d. $3.35 \mathrm{~mm}$, o.d. $4.65 \mathrm{~mm}$ ) and each contained a 3-cm length of oestradiol-17 $\beta$ (Calbiochem-Behring, La Jolla, CA, U.S.A.), as described by Karsch et al. (1973).

At 40 days after implantation, and again at 80 days, 3 oestradiol-implanted ewes and 3 controls were killed. After 200 days, 3 more oestradiol-treated ewes and 3 controls were killed, and the implants were removed from the remaining 5 oestradiol-treated and 4 control ewes. These animals were killed 170 days later, i.e. 370 days after insertion of implants.

In a second experiment, 16 4-year-old Merino ewes were ovariectomized under general anaesthesia. One year later, 5 ewes were fitted subcutaneously with empty implants, and 5 with 4 implants containing oestradiol-173. Three remaining ewes were given 2 implants, and the other 3 received 1 implant. The ewes were killed 140 days later.

Using $\left[{ }^{3} \mathrm{H}\right.$ ]oestradiol, the release rate of the implants was estimated in vitro to be $38 \mu \mathrm{g} / \mathrm{cm}$ per $24 \mathrm{~h}$. Implants were weighed before being inserted into the adult ewes, and weighed again after removal and desiccation. The release rate as estimated by weight loss was $35 \mu \mathrm{g} / \mathrm{cm}$ per $24 \mathrm{~h}$.

Blood samples were collected from all ewes 90 days after implantation, and plasma oestradiol concentrations were measured by radioimmunoassay. In this assay, the intra-assay coefficient of variation was $12 \%$, the inter-assay coefficient of variation was $14 \%$ at $47 \mathrm{pg} / \mathrm{ml}$, and the plasma blank was $6 \mathrm{pg} / \mathrm{ml}$. In adult ovariectomized ewes with 4 implants concentrations were $40 \cdot 1 \pm 4 \cdot 1 \mathrm{pg}$ oestradiol $/ \mathrm{ml}$, in those with 2 implants they were $15.5 \pm 1.8 \mathrm{pg} / \mathrm{ml}$, and values for ewes with 1 implant were too close to the blank value to be reliable. Samples taken at 90 days from the 8 ewe lambs implanted with 3 implants which had not yet been killed had an average plasma oestradiol concentration of $29.2 \pm 3.8 \mathrm{pg} / \mathrm{ml}$.

After the animals were killed by exsanguination and cervical dislocation, the reproductive tracts were fixed in formal saline, and full transverse histological sections were prepared from tissue taken at $6-\mathrm{mm}$ intervals along the cervix. Portions of uterus and vagina were also examined. Sections were stained with haematoxylin and eosin and some cervical sections were also stained with van Gieson's stain for connective tissue.

Microfiche prints of the entire transverse face of the cervical sections were prepared at $\times 23$ magnification as described by Ferrington, Fisher, Herron \& Rowe (1980) and the relative proportions of tissues in the cervix were quantified by a point-counting system. A grid was drawn on clear plastic with lines $1 \mathrm{~cm}$ long, as described by Freere \& Weibel (1967) and the tissue area on which the end of each line fell was recorded. To discriminate changes within the lamina propria, a line was drawn on each print around the bases of the cervical crypts, to define that part of the lamina propria in the cervical folds. A second line was drawn at the junction of the lamina propria and the muscularis layer, so that the relative amounts of lamina propria below the cervical folds could be estimated.

Sections from two segments in each of the cervical, middle and caudal cervix were measured for each animal and the average of the 6 sections was determined for each sheep. In the first experiment, control and treated groups were compared at each time using the average for each animal by Student's $t$ test. In the dose-rate study, results were examined using analysis of variance and regression analysis. 


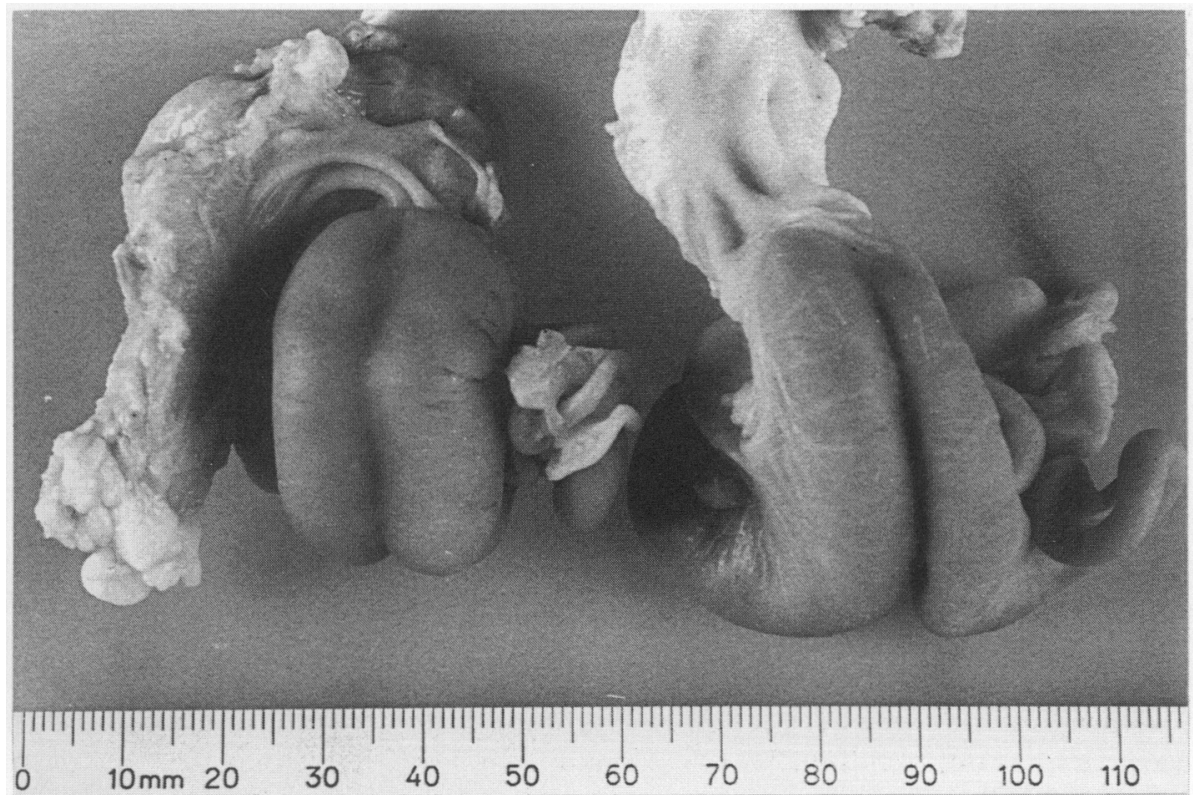

Fig. 1. Sharp delineation of the uterine horns in a ewe (right) treated for 200 days with oestradiol-17 $\beta$, compared with the more pronounced inter-cornual membrane in a control ewe (left).

(a)

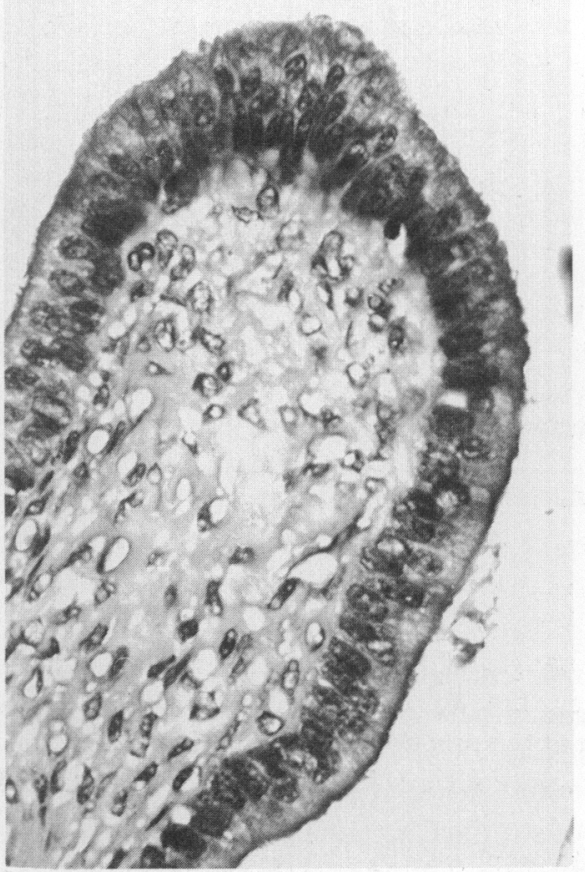

(b)

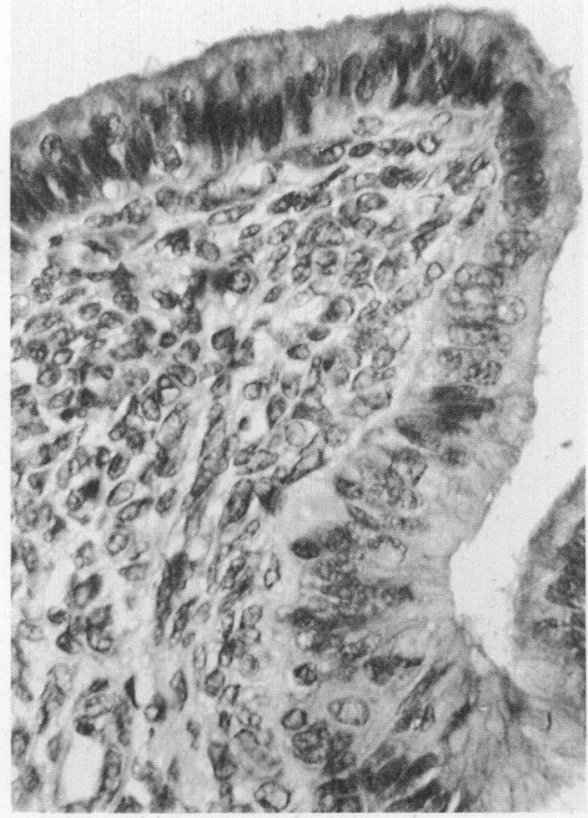

Fig. 2. Cervical folds from (a) a control ewe and (b) a ewe treated with oestradiol- $17 \beta$ for 200 days. The lamina propria of the treated ewe contains many non-inflammatory stromal cells. $\times 425$. 


\section{Results}

\section{Experiment 1}

In oestrogen-treated ewes killed at 200 days, the vaginal wall was thickened and the lumen contained thick creamy inspissated material. The body of the uterus was diminished, so that the uterine horns ran separately almost to the cervix (Fig. 1). The cervix was broader and slightly shorter than controls, and felt softer. Histologically, the cranial half of the cervix contained many stromal cells (Fig. 2) which in some areas were densely packed into bands under the epithelium. The nuclei had a more open appearance than those of mononuclear inflammatory cells (Fig. 2), which also occurred in some animals. Few plasma cells were seen. The cervical folds appeared shorter and wider in the treated animals. The collagen in the cervical folds appeared normal, but the collagen in the lamina propria adjacent to the first longitudinal layer of smooth muscle appeared to have been replaced by less dense connective tissue. This tissue contained many tubular glands cut in cross-section.

At 40 days, small bands of stromal cells were present in the cervical folds of treated ewes, but the ratio of folds to lamina propria tissue was not obviously smaller. Differences between treated and control cervices were obvious at 80 days. The number of stromal cells and the reduced ratio of folds to lamina propria tissue (Table 1) was similar to that seen in treated ewes killed at 200 days.

Table 1. Mean \pm s.e.m. areas $\left(\mathrm{mm}^{2}\right)$ of components of the cervix of ewes treated with oestradiol for different periods

\begin{tabular}{|c|c|c|c|c|}
\hline & $\begin{array}{l}\text { No. of } \\
\text { ewes }\end{array}$ & Folds & Lamina propria & Lumen \\
\hline \multicolumn{5}{|l|}{40 days } \\
\hline Control & 3 & $8 \cdot 79 \pm 3 \cdot 80$ & $1.17 \pm 0.19$ & $9 \cdot 10 \pm 6 \cdot 27$ \\
\hline Treated & 3 & $6.89 \pm 1.07$ & $3.89 \pm 1.31$ & $5 \cdot 15 \pm 0.31$ \\
\hline \multicolumn{5}{|l|}{80 days } \\
\hline Control & 3 & $7.97 \pm 3.26$ & $3 \cdot 80 \pm 1 \cdot 11$ & $5.99 \pm 2.92$ \\
\hline Treated & 3 & $5.24 \pm 0.52$ & $8.22 \pm 0.73^{*}$ & $3.51 \pm 0.42$ \\
\hline \multicolumn{5}{|l|}{200 days } \\
\hline Control & 3 & $11.77 \pm 1.56$ & $6.09 \pm 0.17$ & $4.38 \pm 0.96$ \\
\hline Treated & 3 & $9.04 \pm 0.96$ & $9.81 \pm 0.65^{* *}$ & $4 \cdot 11 \pm 0.71$ \\
\hline \multicolumn{5}{|c|}{$\begin{array}{l}200 \text { days }+170 \text { days } \\
\text { of withdrawal }\end{array}$} \\
\hline Control & 4 & $10.71 \pm 0.75$ & $6.89 \pm 0.88$ & $3.48 \pm 0.65$ \\
\hline Treated & 5 & $4.78 \pm 0.90^{* *}$ & $8.45 \pm 1.04$ & $2.46 \pm 0.61$ \\
\hline
\end{tabular}

${ }^{*} P<0.05,{ }^{* *} P<0.01$, compared with control value at that time.

In control ewes the caudal third of the cervix was covered by low stratified squamous epithelium, while the cranial cervix had low columnar epithelium. In all the treated ewes, the stratified squamous epithelium was thicker, and extended over the caudal half of the cervix. The columnar cells were also slightly taller in treated ewes.

Some of the features characteristic of oestrogenic stimulation regressed in the ewes killed 170 days after removal of the implants. The distribution of stratified squamous epithelium was similar in the control and treated animals. However, the increase in lamina propria had persisted, as had the tubular glands and the loss of cervical folds (Fig. 3). In fact, the differences in appearance between the treated and control groups were even more marked after removal of the implants.

As seen in Fig. 3, the difference in appearance is due largely to smaller folds, which seem to have been replaced by lamina propria containing glands. The quantitative data support the visual 

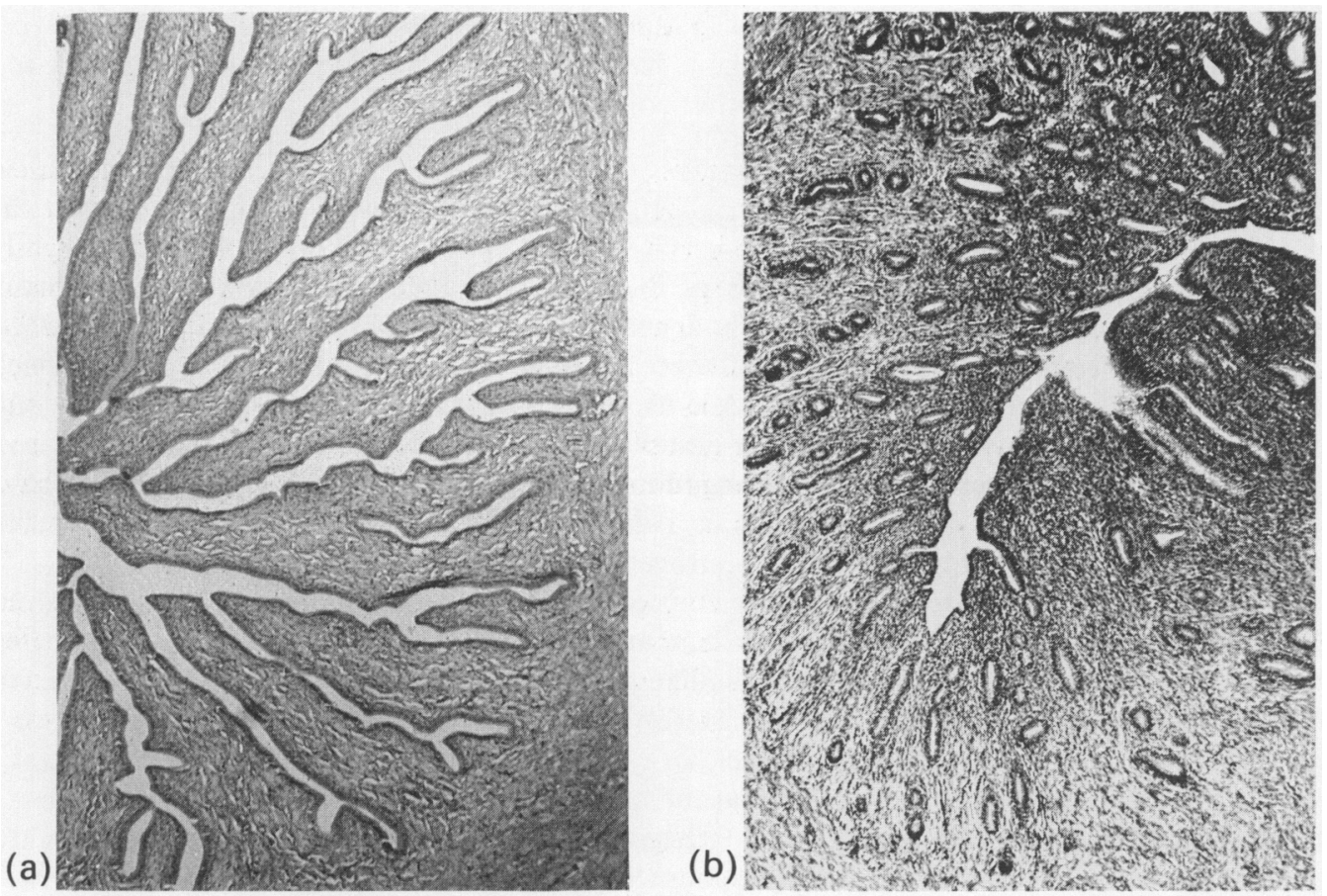

Fig. 3. Transverse cross-section at mid cervix from (a) a control ewe and (b) a ewe treated for 200 days with oestradiol-17 $\beta$, followed by withdrawal for 170 days before slaughter. The endocervix of the treated ewe has an architectural appearance similar to that of the endometrium. $\times 40$.

Table 2. Mean ( \pm s.e.m.) values for components of cervix in ewes treated with oestradiol implants

\begin{tabular}{|c|c|c|c|c|c|}
\hline \multirow[b]{2}{*}{$\begin{array}{l}\text { No. of } \\
\text { implants }\end{array}$} & \multirow[b]{2}{*}{$\begin{array}{l}\text { No. of } \\
\text { ewes }\end{array}$} & \multicolumn{4}{|c|}{ Component of cervix $\left(\mathrm{mm}^{2}\right)$} \\
\hline & & Folds & Lamina propria & Lumen & $\begin{array}{c}\text { Glandular } \\
\text { cross-sections }\end{array}$ \\
\hline 0 & 5 & $4.44 \pm 0.92$ & $3.86 \pm 0.63$ & $3.29 \pm 0.46$ & $124 \pm 22$ \\
\hline 1 & 3 & $4 \cdot 41 \pm 0 \cdot 36$ & $9.05 \pm 1.31$ & $1 \cdot 80 \pm 0 \cdot 11$ & $117 \pm 27$ \\
\hline 2 & 3 & $4 \cdot 38 \pm 0 \cdot 87$ & $9.97 \pm 4.69$ & $1.90 \pm 0.84$ & $200 \pm 107$ \\
\hline 4 & 5 & $5 \cdot 26 \pm 1 \cdot 30$ & $12.66 \pm 2.48$ & $2 \cdot 32 \pm 0 \cdot 36$ & $263 \pm 84^{*}$ \\
\hline
\end{tabular}

${ }^{*} P<0.05$, regression analysis.

impression (Table 1); folds made up a smaller proportion of the endocervix in the treated ewes. The area of the endocervix was smaller in the treated ewes (Table 1), and the cervix weighed less $(3.09 \pm 0.28$ vs $4.04 \pm 0.17 \mathrm{~g}, P<0.05)$. Therefore, although the lamina propria made up a larger proportion of the endocervix in treated ewes, the total amount of lamina propria was similar to that seen in controls.

\section{Experiment 2}

The ewes in this study developed changes in appearance of the cervix similar to those described above. The area of lamina propria was increased in all the treated groups, but there was no obvious 
effect of the number of implants (Table 2). The numbers of cross-sections of glands in the cervix increased $(P<0.05)$ with the number of implants but there was no consistent effect of exposure to oestradiol on the area of either the lumen, or the cervical folds (Table 2).

\section{Discussion}

Oestrogen can produce two different kinds of histological change in the cervix of the ewe. Short-term exposure to oestrogen produces those changes commonly observed in adult mammals, including stratified squamous metaplasia of the epithelium and increased height of columnar epithelial cells (Bell, Casida \& Darlow, 1941; Adams, 1977). Longer exposure to oestradiol changed the cervix in a manner which has not been described in other species. The cervix assumed an appearance similar to that produced by prolonged exposure to oestrogenic clover pasture (Adams, 1976; Heydon \& Adams, 1977; Lightfoot \& Adams, 1979) and, as in clover disease, this abnormality remained after the exposure to oestrogen was terminated.

Prolonged exposure to oestradiol-17 $\beta$ enhanced the bicornuate nature of the uterus and reduced the proportion of the genital tract which appeared to be cervix. Oestradiol and diethylstilboestrol have been reported to cause uterine-like cells to appear in the cervix of mice (Forsberg, 1969; Plapinger \& Bern, 1979) and women (Herbst, Kurman \& Scully, 1972) and to produce a bicornuate uterus in women (Kaufman, Binder, Gray \& Adam, 1977), provided that treatment was given during organogenesis. It is possible that the mechanisms by which oestrogen affects differentiation of the Müllerian duct during organogenesis in other species are still functional to a slight. extent in the adult ewe. This suggestion is consistent with the hypothesis that the permanent structural and functional changes observed in adult ewes after prolonged exposure to oestrogenic pasture are similar in nature to those occurring during sexual differentiation in utero (Adams, 1981b; Adams \& Martin, 1983). Although re-differentiation of an organ after organogenesis is unusual in mammals, this seems to be the simplest hypothesis to explain the features observed in this study.

The amount of oestradiol used in the present study was above the physiological range. During the oestrous cycle, peripheral levels of oestrogen average around $5 \mathrm{pg} / \mathrm{ml}$, rising to about $13 \mathrm{pg} / \mathrm{ml}$ at estrus (Yuthasastrakosol, Palmer \& Howland, 1975). In the last part of pregnancy, oestradiol$17 \beta$ values average about $25 \mathrm{pg} / \mathrm{ml}$, while oestrone concentrations reach $70 \mathrm{pg} / \mathrm{ml}$ (Thompson \& Wagner, 1974). In the present study, ewes with 4 implants were estimated to have a peripheral plasma concentration of $40 \mathrm{pg}$ oestradiol $-17 \beta / \mathrm{ml}$. This is above the value of $20 \mathrm{pg} / \mathrm{ml}$ reported by Karsch \& Foster (1975) for wethers fitted with 5 similar implants, possibly because the sheep in the present study were of a different sex and breed.

It is probable that permanent alteration of the cervix can be produced by amounts of oestrogen within the physiological range. In the present study, a similar response was produced by 1 and 4 implants (Table 2), suggesting that the maximum response had been achieved. Furthermore, permanent abnormalities can be produced on clover pasture, which has an oestrogenicity equivalent to around $10 \mu \mathrm{g}$ diethylstilboestrol per day (Bennett, Morley \& Axelsen, 1967), while the dose of diethylstilboestrol needed to bring a ewe into oestrus is $27 \mu \mathrm{g} /$ day (Robinson \& Reardon, 1961). Controlled dose-response studies are needed to determine whether the morphogenic change can be produced by physiological amounts of oestradiol. If so, it will be difficult to understand why the abnormality is not seen in ewes as a result of exposure to endogenous oestrogen. It is not because ewes lose the ability to produce the response with age, because similar changes occurred in the present study in prepubertal animals and in mature, ovariectomized animals. It is possible that other hormones such as prolactin (Mori, Nagasawa \& Takahashi, 1981), progesterone or relaxin are involved in the development of the abnormality.

I thank Dr G. B. Martin and Dr J. Ford for the radioimmunoassay of oestradiol-17ß; M. R. Sanders for the histological preparations; and I. M. Adams for assistance with photography. 


\section{References}

Adams, N.R. (1976) Pathological changes in the tissues of ewes with clover disease. J. comp. Path. 86, 29-35.

Adams, N.R. (1977) Morphological changes in the organs of ewes grazing oestrogenic clover. Res, vet. Sci. 22, 216-221.

Adams, N.R. (1981a) Cervical histology as a measure of the response of ewes to large amounts of oestrogen. Proc. Aust. Soc. Reprod. Biol. 13, 42, Abstr.

Adams, N.R. (1981b) A changed responsiveness to oestrogen in ewes with clover disease. J. Reprod. Fert., Suppt. 30, 223-230.

Adams, N.R. (1983) Persistent uterine-like metaplasia of the endocervix in ewes exposed to large amounts of estradiol-17ß. Biol. Reprod. 28, Suppl. 1, 128, Abstr. 192.

Adams, N.R. \& Martin, G.B. (1983) Effects of oestradiol on plasma concentrations of luteinizing hormone in ovariectomized ewes with clover disease. Aust. J. biol. Sci. 36, 295-303.

Bell, T.D., Casida, L.E. \& Darlow, A.E. (1941) Effects of estrogen and progesterone upon the genital tract of the ewe. Endocrinology 28, 441-449.

Bennett, D., Morley, F.W.H. \& Axelsen, A. (1967) Bioassay response of ewes to legume swards. II. Uterine weight response from swards. Aust. J. agric. Res. 18, 495-504.

Ferrington, D.G., Fisher, G.R., Herron, P. \& Rowe, M.J. (1980) A simple accurate method for reproducing details of histological sections using a microfiche printer. Neurosci. Lett. 19, 51-53.

Forsberg, J.-G. (1969) The development of atypical epithelium in the mouse uterine cervix and vaginal fornix after neonatal oestradiol treatment. Br. J. exp. Path., 50, 187-195.

Freere, R.H. \& Weibel, E.R. (1967) Stereologic techniques in microscopy. J. Roy. Microscop. Soc. 87, 24-34.

Herbst, A.L., Kurman, R.J. \& Scully, R.E. (1972) Vaginal and cervical abnormalities after exposure to stilbestrol in utero. Obstet. Gynec. 40, 287-298.

Heydon, R.A. \& Adams, N.R. (1977) Histochemical studies on cervical glands in ewes with clover disease. J. comp. Path. 87, 353-361.

Heydon, R.A. \& Adams, N.R. (1979) Comparative morphology and mucus histochemistry of the ruminant cervix: differences between crypt and surface epithelium. Biol. Reprod. 21, 557-567.
Karsch, F.J. \& Foster, D.L. (1975) Sexual differentiation of the mechanism controlling the preovulatory discharge of luteinizing hormone in sheep. Endocrinology 97, 373-379.

Karsch, F.J., Dierschke, D.J., Weick, R.F., Yamaji, T., Hotchkiss, J. \& Knobil, E. (1973) Positive and negative feedback control by estrogen of luteinizing hormone secretion in the rhesus monkey. Endocrinology 92, 799-804.

Kaufman, R.H., Binder, G.L., Gray, P.M. \& Adam, E. (1977) Upper genital tract changes associated with exposure in utero to diethylstilbestrol. Am.J. Obstet. Gynec. 128, 51-59.

Lightfoot, R.J. (1974) A look at recommendations for the control of infertility due to clover disease in sheep. Proc. Aust. Soc. Anim. Prod. 10, 113-121.

Lightfoot, R.J. \& Adams, N.R. (1979) Changes in cervical histology in ewes following prolonged grazing on oestrogenic subterranean clover. J. comp. Path. 89, 367--373.

Lightfoot, R.J., Croker, K.P. \& Neil, H.G. (1967) Failure of sperm transport in relation to ewe infertility following prolonged grazing on oestrogenic pastures. Aust. J. agric. Res. 18, 755-765.

Mori, T., Nagasawa, H. \& Takahashi, S. (1981) The induction of adenomyosis in mice by intrauterine pituitary isografts. Life Sci. 29, 1277-1282.

Plapinger, L. \& Bern, H.A. (1979) Adenosis-like lesions and other cervicovaginal abnormalities in mice treated perinatally with estrogen. $J$. Natl. Cancer Inst. 63, 507-518.

Raynaud, F. (1973) Physiologie du col de l'utérus de la brebis. Effet d'un progestagène de synthèse: l'acétate de flurogestone. Annls Biol. anim. Biochim. Biophys. 13, 335-346.

Robinson, T.J. \& Reardon, T.F. (1961) The activity of a number of oestrogens as tested in the spayed ewe. $J$. Endocr. 23, 97-107.

Thompson, F.N. \& Wagner, W.C. (1974) Plasma progesterone and oestrogens in sheep during late pregnancy: contribution of the maternal adrenal and ovary. J. Reprod. Fert. 41, 57-66.

Yuthasastrakosol, P., Palmer, W. M. \& Howland, B.E. (1975) Luteinizing hormone, oestrogen and progesterone levels in peripheral serum of anoestrous and cyclic ewes as determined by radioimmunoassay. J. Reprod. Fert. 43, 57-65 